\title{
Changes in Growth and Antioxidant Contents of Romaine Lettuce by Different UV Spectra
}

\author{
Sung Woo Jeong* \\ Research Institute of Industrial Science \& Technology(RIST), Pohang 37673, Korea
}

\begin{abstract}
The current study was conducted to determine the influence of irradiations of different UV spectra on plant growth and antioxidant compounds of two romaine lettuce cultivars ('Caesar green' and 'Caesar red'). The UV treatments were consisted of three UV spectra; UV-A (314-400nm), FUV-B (290-400nm) and UV-B (274-400nm), using fluorescent lamps and irradiated for 2 hours at nighttime for 11 days under greenhouse. As the results, there were no differences in growth parameters and antioxidant compounds between UV-A treatments and control in two cultivars. On the other hand, FUV-B treatment increased significantly the contents of UV absorbing compounds, $\beta$ -carotene, lutein, total phenolic compounds and anthocyanin in caesar green cultivar. It also increased UV absorbing compounds, total phenolic compounds and anthocyanin contents in caesar red cultivar without any growth reduction. UV-B treatment, however, decreased lutein, chlorophyll contents and caused growth reduction and physiological damage such as leaf chlorosis and wrinkle in both cultivars. Overall, the results indicate that supplemental FUV-B treatment, at least in part, may increase antioxidant compounds without any inhibitory effect on shoot growth in romaine lettuce. The results of the current study present a useful practical technique for increasing antioxidant compounds of romaine lettuce production in greenhouse horticulture.
\end{abstract}

Keywords: cultivation strategy, fluorescent light, greenhouse, irradiation

\section{Introduction}

The growth and development of plants are affected not only by the intensity of light but also by wavelengths. Visible rays $(400-700 \mathrm{~nm})$ have effective wavelengths for photosynthesis, and near infrared (NIR) rays (700-800nm) play a role in promoting an increase in the length of stems (Jeong et al., 2014). Ultraviolet (UV) rays (400nm or lower) suppress the growth of stems and thicken leaves (Jeong and Huh, 2010). UV rays are also involved in determining the shape of plants as well as causing changes in metabolites, and have been reported to biosynthesize antioxidant compounds such as flavonoid and anthocyanin (Kakani et al., 2003; Jeong and Huh, 2010). Antioxidant compounds are, in general, known to be effective in treating and preventing aging, cardiovascular diseases and metabolic diseases. Plants accumulate antioxidant compounds as one of the defense mechanisms against environmental stress in order to remove active oxygen species

\footnotetext{
This work was supported by Korea Institute of Planning and Evaluation for Technology in Food, Agriculture, Forestry (IPET) through Technology Commercialization Support Program, funded by Ministry of Agriculture, Food and Rural Affairs (MAFRA) (315028-03-3-HD020)

Received: August 13, 2018, Revised: August 20, 2018, Accepted: September 5, 2018

First author: Sung Woo Jeong, E-mail: swjeong2014@rist.re.kr, ORCID: 0000-0002-8762-8647

*Corresponding author: Sung Woo Jeong, E-mail: swjeong2014@rist.re.kr, ORCID: 0000-0002-8762-8647
} 
produced by stress (Jain et al., 2003). Flavonoid in epidermal tissues and vacuoles in the leaves of plants absorb UV rays only, not visible rays, to protect the body of plants from UV rays (Barsig and Malz, 2000). An increase in phenolic compounds and UV absorbing compounds has been reported as a phenomenon to protect the body of plants from UV rays (Cen and Bornman, 1993; Smith et al., 2000).

Behn et al. (2010) suggested a method for increasing the content of flavonoid in lettuce grown in a greenhouse by varying the UV penetration rate of covering materials. The content of beneficial antioxidant compounds can be increased using other methods, such as manipulating related genes and employing cultivation technology. Cultivation technology that controls UV rays is expected to improve the quality and added value of fresh produce.

Meanwhile, some studies have reported the physiological disorders and reduced growth of plants caused by UV rays. Exposure to UV rays is reported to decrease the photosynthesis of crops (Stepleton, 1992), destroy chlorophyll (Zhang et al., 2005), and increase lipid peroxidation (Ervin et al., 2004), which damages plants both directly and indirectly. Yao et al. (2006) reported that oxidative stress in cucumber and beans can be varied depending on the wavelength of UV rays. The effects of controlling UV rays on the growth and physiological response of plants seem to differ depending on how to control UV rays. The quality and added value of crops can be improved by selecting beneficial UV wavelengths to the growth of crops and antioxidant compounds in them. However, there is only a limited amount of information available about methods for treating UV rays using artificial light in cultivating lettuce. Against this backdrop, this study aimed to analyze the effects of treating Lactuca sativa with different wavelengths of UV light using fluorescent lamps on the growth of Lactuca sativa and the content of antioxidant compounds in it.

\section{Methods}

\section{Testing Materials and Growth Evaluation}

This study was conducted in a glass greenhouse in Gyeongsang National University. Two Lactuca sativa cultivars ('Caesar green' and 'Caesar red') bred and sold by Asiaseed were used as a testing material. Seeds were sown in a plant growth chamber where temperature and humidity are constantly maintained on March 25. Seedlings were raised in a 72-cell plastic tray until four normal leaves are grown. On April 18, the 24th day after sowing, uniform seedlings were transplanted into plastic pots (diameter: 100mm) filled with gardening bed soil. After transplanting, they were cultivated within a glass greenhouse until harvesting. Using hot-water heating and ventilation fans, a proper temperature for growth was maintained, and the average temperature of the greenhouse was maintained at $25.5 / 16.3^{\circ} \mathrm{C}($ day/night) during this experiment. Nutrients and water were supplied using bottom watering system and a standard nutrient solution for lettuce commonly used in horticultural experimental stations was supplied (Lee et al., 1999). UV treatments were performed using UV-A fluorescent lamps (F20T 10BLB; Sankyo Denki, Japan) and UV-B fluorescent lamps (G40T 10E; Sankyo Denki, Japan), and a cellulose diacetate film (thickness: $0.08 \mathrm{~mm}$ ) was placed on some UV-B fluorescent lamps to control their wavelengths. UV treatments were performed for 2 hours per day at night and the time was set on a timer. The distance between the UV lamps and lettuce was maintained at $50 \mathrm{~cm}$. The control group was not treated with UV fluorescent lamps. The wavelengths of UV treatments applied in this study are as shown in Figure 1. The wavelengths of the UV-A lamp treatment were 314-400nm, and those of the filtered UV-B (FUV-B) lamp treatment were 290-400nm. The wavelengths of the UV-B lamp treatment were the shortest (274-400nm). Each treatment (a total of 3 treatments) was repeated three times, and 12 units were treated for each repeated treatment.

Plants were harvested and their growth was analyzed 11 days after UV treatments. The length, width, number and area of leaves and their dry weight were measured. The area of leaves was measured using a leaf area meter (Li-3000, 2007, 


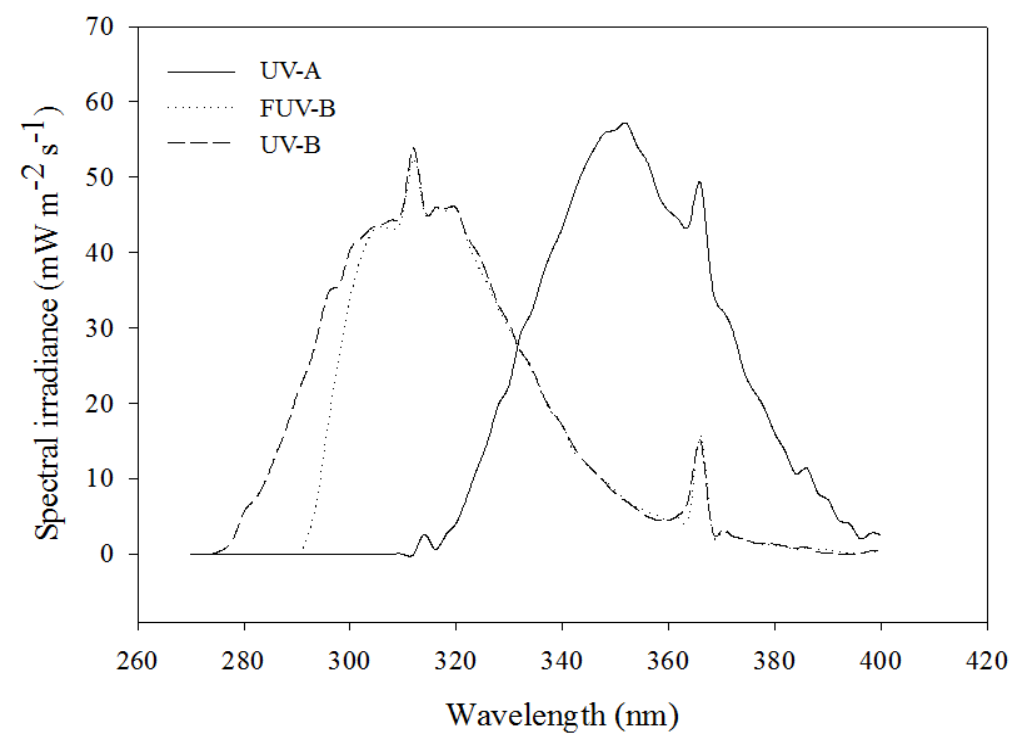

Figure 1. Spectral irradiance with UV-A, FUV-B and UV-B used in this experiment (measurement was determined at plant levels).

Li-Cor, USA), and their dry weight was measured after measuring their fresh weight and drying them in a hot-air dryer at $80^{\circ} \mathrm{C}$ for 72 hours.

\section{Analysis Methods}

Chlorophyll was analyze based on the method of Lichtenthaler (1987) using the following process: $0.5 \mathrm{~g}$ of fresh leaves were homogenized in $100 \%$ acetone solvent, and were centrifuged at $4^{\circ} \mathrm{C}$ for 10 minutes $(2,800 \times \mathrm{g})$. After that, the supernatant was decanted and its absorbance (A) was measured and quantified at $661.6 \mathrm{~nm}$ and $644.8 \mathrm{~nm}$.

Anthocyanin was analyzed based on the method of Rabino and Macinelli (1986) using the following process: $0.5 \mathrm{~g}$ of fresh leaves were extracted in methanol solvent that contains $1 \% \mathrm{HCl}$ for 48 hours, and were filtered using a filter paper (No. 5). After that, their absorbance (A) was measured and quantified at 530nm and $657 \mathrm{~nm}$.

UV absorbing compounds were analyzed based on the method of Smith et al. (2000) using the following process: two leaf samples that were bored using a $10 \mathrm{~mm}$ cork borer were extracted in $5 \mathrm{ml}(\mathrm{MeOH}: \mathrm{HCl}=99: 1, \mathrm{v} / \mathrm{v})$ solvent at $4^{\circ} \mathrm{C}$ for 48 hours, and their absorbance (A) was measured and quantified at $305 \mathrm{~nm}$ using a UV spectrophotometer (Uvikon XL UV-vis, 2006, Biotek Instruments, Italy).

$\beta$-carotene and lutein were analyzed using HPLC based on the method of Cadwell and Britz (2006). Total phenolic compounds were analyzed based on the method of Singh et al. (1999).

Inorganic compounds were analyzed using the following process: $0.2 \mathrm{~g}$ dry leaves were added with $10 \mathrm{ml}$ decomposition solution $\left(\mathrm{H}_{2} \mathrm{SO}_{4}: \mathrm{HClO}_{4}: \mathrm{H}_{2} \mathrm{O}=2: 9: 5\right.$, v/v/v) for wet decomposition, and their total nitrogen content was measured using the Kjedahl method (2300 Kjeltec Analyzer Unit, 2003, Foss Co., USA). Phosphoric acid was measured using a spectrophotometer after decomposing using the Vanadate method. Calcium, magnesium and potassium were measured using ICP.

\section{Statistical Analysis}

The data obtained in this study were statistically analyzed using SAS software (SAS Institute, Cary, NC), and 
differences between treatments were analyzed using the Tukey's test.

\section{Results and Discussion}

Table 1 shows the effects of the UV-A, FUV-B and UV-B treatments using fluorescent lamps on the growth of Caesar green and Caesar red romaine lettuce cultivars. The UV-A treatment was not found to affect the growth of the two romaine lettuce cultivars compared to the control group. Yun et al. (2003) reported that treating with the wavelengths of UV-A for 10 minutes per day for 10 days did not affect or slightly increased the growth of spinach, crown daisy and lettuce, and Green et al. (1974) reported that the wavelengths longer than 313nm do not affect the growth of plants. Meanwhile, Krizek et al. $(1997,1998)$ stated that cucumber and lettuce grown in a greenhouse where the wavelengths of UV-A were reflected were grown better than those grown in a greenhouse where the wavelengths of UV-A passed through, and Yao et al. (2006) also stated that treating seedlings of beans and cucumber with UV-A fluorescent lamps for 6 hours per day reduced the length and area of leaves. Changes in the growth of crops by UV-A treatments seem to vary depending on the method and time of treatments. The FUV-B treatment of which lamps were covered with an acetate film showed different growth results between the two cultivars. The length of Caesar green lettuce leaves and the dry weight of their subterranean part were reduced compared to those that were not treated, but there was no statistically significant difference between Caesar green lettuce leaves and those that were not treated. Smith et al. (2000) stated that plants with a high growth speed is more sensitive to UV rays than those with a low growth speed. It will be necessary to further research on this in detail. Meanwhile, the UV-B treatment statistically significantly reduced the growth of Caesar green and Caesar red romaine lettuce, and the dry weight of their aerial part was reduced by $34 \%$ and $41 \%$ respectively compared to non-treated romaine lettuce. Since the number of leaves treated with the wavelengths of UV-B was low, they relatively slowly appeared above the soil, and some leaves were rolled and turned yellow (data not shown). The continuous treatment of UV-B seems to negatively affect the quality of romaine lettuce. Yun et al. (2003) reported that the reduced growth of spinach, crown daisy and lettuce differed depending on the type of UV treatments, and that the UV-B treatment significantly reduced the growth of the plants compared to the non-treated group. The results of this study also showed differences in the growth of romaine lettuce depending on the wavelength of UV rays and the cultivar of romaine lettuce.

Table 1. Responses of irradiations of different UV spectra on growth of two romaine lettuce(Latuca sativa)

\begin{tabular}{|c|c|c|c|c|c|c|}
\hline \multirow{2}{*}{ UV treatments } & \multirow{2}{*}{$\begin{array}{l}\text { Leaf length } \\
(\mathrm{cm})\end{array}$} & \multirow{2}{*}{$\begin{array}{l}\text { Leaf width } \\
\quad(\mathrm{cm})\end{array}$} & \multirow{2}{*}{ No. of leaves } & \multirow{2}{*}{$\begin{array}{l}\text { Total leaf area } \\
\quad\left(\mathrm{cm}^{2}\right)\end{array}$} & \multicolumn{2}{|c|}{ Dry weight (g/plant) } \\
\hline & & & & & Shoot & Root \\
\hline \multicolumn{7}{|c|}{ Caesar green } \\
\hline Control & $22.3 \mathrm{a}^{\mathrm{z}}$ & $8.1 \mathrm{a}$ & $10.8 \mathrm{a}$ & 506 a & $0.50 \mathrm{a}$ & $0.082 \mathrm{a}$ \\
\hline UV-A (314-400nm) & $20.5 \mathrm{ab}$ & $7.7 \mathrm{a}$ & $11.7 \mathrm{a}$ & $497 \mathrm{a}$ & $0.47 \mathrm{a}$ & $0.077 \mathrm{ab}$ \\
\hline FUV-B (290-400nm) & $19.1 \mathrm{~b}$ & $6.8 \mathrm{a}$ & $11.8 \mathrm{a}$ & $406 \mathrm{a}$ & $0.45 \mathrm{a}$ & $0.069 \mathrm{~b}$ \\
\hline UV-B (274-400nm) & $14.1 \mathrm{c}$ & $5.4 \mathrm{~b}$ & $8.5 \mathrm{~b}$ & $196 \mathrm{~b}$ & $0.33 \mathrm{~b}$ & $0.045 \mathrm{c}$ \\
\hline \multicolumn{7}{|c|}{ Caesar red } \\
\hline Control & $18.5 \mathrm{a}$ & $6.9 \mathrm{a}$ & $11.8 \mathrm{a}$ & $295 \mathrm{a}$ & $0.37 \mathrm{a}$ & $0.041 \mathrm{a}$ \\
\hline UV-A (314-400nm) & $17.9 \mathrm{a}$ & $6.6 \mathrm{a}$ & $11.5 \mathrm{a}$ & $312 \mathrm{a}$ & $0.39 \mathrm{a}$ & $0.047 \mathrm{a}$ \\
\hline FUV-B (290-400nm) & $17.6 \mathrm{a}$ & $6.4 \mathrm{a}$ & $10.7 \mathrm{a}$ & $280 \mathrm{a}$ & $0.36 \mathrm{a}$ & $0.038 \mathrm{a}$ \\
\hline UV-B (274-400nm) & $12.3 \mathrm{~b}$ & $5.1 \mathrm{~b}$ & $8.1 \mathrm{~b}$ & $154 \mathrm{~b}$ & $0.22 \mathrm{~b}$ & $0.028 \mathrm{~b}$ \\
\hline
\end{tabular}

${ }^{\mathrm{z}}$ Values with the same letter within column are not significantly different at $p<.05$ according to Tukey's H.S.D. test. 
Table 2. Responses of different UV spectra on UV absorbing compounds, $\beta$-Carotene, lutein, and total phenol compounds in two romaine lettuce(Latuca sativa)

\begin{tabular}{lcccc}
\hline UV treatments & $\begin{array}{c}\text { UV absorbing } \\
\text { compounds }\end{array}$ & $\begin{array}{c}\beta \text {-carotene } \\
\left(\mu \mathrm{g} \cdot \mathrm{g}^{-1} \mathrm{FW}\right)\end{array}$ & $\begin{array}{c}\text { Lutein } \\
\left(\mu \mathrm{g} \cdot \mathrm{g}^{-1} \mathrm{FW}\right)\end{array}$ & $\begin{array}{c}\text { Total phenol } \\
\left(\mathrm{mg} \cdot 100 \mathrm{~g}^{-1} \mathrm{FW}\right)\end{array}$ \\
\hline & & Caesar green & \\
Control & $0.591 \mathrm{c}^{\mathrm{z}}$ & $34.1 \mathrm{c}$ & $50.2 \mathrm{~b}$ & $24.3 \mathrm{~b}$ \\
UV-A $(314-400 \mathrm{~nm})$ & $0.644 \mathrm{bc}$ & $56.4 \mathrm{~b}$ & $57.8 \mathrm{ab}$ & $27.8 \mathrm{~b}$ \\
FUV-B $(290-400 \mathrm{~nm})$ & $0.794 \mathrm{~b}$ & $86.0 \mathrm{a}$ & $68.9 \mathrm{a}$ & $36.4 \mathrm{a}$ \\
UV-B $(274-400 \mathrm{~nm})$ & $1.151 \mathrm{a}$ & $53.8 \mathrm{~b}$ & $36.1 \mathrm{c}$ & $22.0 \mathrm{~b}$ \\
& & & \\
Control & $0.245 \mathrm{~b}$ & Caesar red & $47.1 \mathrm{c}$ \\
UV-A (314-400nm) & $0.257 \mathrm{~b}$ & $47.3 \mathrm{a}$ & $20.5 \mathrm{bc}$ \\
FUV-B (290-400nm) & $0.283 \mathrm{~b}$ & $50.6 \mathrm{a}$ & $53.7 \mathrm{a}$ & $30.3 \mathrm{a}$ \\
UV-B (274-400nm) & $0.355 \mathrm{a}$ & $50.8 \mathrm{a}$ & $51.7 \mathrm{a}$ & $22.9 \mathrm{~b}$ \\
\hline
\end{tabular}

${ }^{\mathrm{z}}$ Values with the same letter within column are not significantly different at $p<.05$ according to Tukey's H.S.D. test.

Table 2 shows the results of analyzing the effects of different UV treatments on UV absorbing compounds, $\beta$-carotene, lutein and phenolic compounds in romaine lettuce. The content of UV absorbing compounds in the two cultivars was high in the short wavelength range. Plants in general have evolved to adapt to external environment, and have developed defense functions against UV rays. Once UV rays are absorbed by plants, the plants accumulate UV absorbing compounds in order to reduce the amount of UV rays that reach their lower part, which seems to be related to their protection against UV rays (Kim and Cho, 2001). Kakani et al. (2003) reported that the content of UV absorbing compounds in cowpea leaves exposed to UV-B was increased by up to $300 \%$. The content of $\beta$-carotene, lutein and phenolic compounds in the Caesar green leaves in the FUV-B group was statistically significantly increased, and the content of $\beta$-carotene was increased by up to $152 \%$ compared to that in non-treated Caesar green lettuce. The content of $\beta$-carotene in the Caesar green leaves in the UV-A and UV-B groups was also increased, but there was no change or a slight decrease in the content of lutein and phenolic compounds compared to non-treated Caesar green lettuce.

There was a statistically significant increase in the content of phenolic compounds in Caesar red lettuce in the FUV-B group, while there was no significant change in the content of $\beta$-carotene and lutein after treating with UV rays. The content of $\beta$-carotene and lutein in green-colored Caesar green leaves showed a statistically significant increase, while there was no significant difference or even a slight decrease in the content of $\beta$-carotene and lutein in red-colored Caesar red leaves, which can be attributed to the wavelengths of UV rays. Cadwell and Britz (2006) stated that UV-B treatment used as a supplemental lighting increased the content of carotenoids in green-colored lettuce leaves but reduced the content in red-colored lettuce leaves. These results of this study seem to indicate that changes in the content of antioxidant compounds caused by UV treatments have a different impact on different cultivars.

Table 3 shows changes in the content of chlorophyll and anthocyanin in romaine leaves depending on the treatment of different UV wavelengths. The content in Caesar green leaves was significantly reduced by the UV-B treatment, and that in Caesar red leaves was also low. On the contrary, the UV-A and FUV-B treatments were not found to affect the content of chlorophyll in the two romaine lettuce calivars. These results seem to indicate that the continuous treatment of UV-B seems to negatively affect the growth of romaine lettuce and the production of chlorophyll. The content of anthocyanin was increased in the F-UVB and UV-B treatment groups, but there was no change in the UV-A treatment group. Anthocyanin is known to remove active oxygen caused by UV-B and protect cells (Singh et al., 1999). In addition, certain 
Table 3. Responses of irradiations of different UV spectra on photosynthetic pigments in two romaine lettuce(Latuca sativa)

\begin{tabular}{lcccc}
\hline UV treatments & $\begin{array}{c}\text { Chlorophyll a } \\
\left(\mathrm{mg} \cdot \mathrm{g}^{-1} \mathrm{FW}\right)\end{array}$ & $\begin{array}{c}\text { Chlorophyll b} \\
\left(\mathrm{mg} \cdot \mathrm{g}^{-1} \mathrm{FW}\right)\end{array}$ & $\begin{array}{c}\text { Total chlorophyll } \\
\left(\mathrm{mg} \cdot \mathrm{g}^{-1} \mathrm{FW}\right)\end{array}$ & $\begin{array}{c}\text { Anthocyanin } \\
\left(\mu \mathrm{g} \cdot \mathrm{g}^{-1} \mathrm{FW}\right)\end{array}$ \\
\hline & & Caesar green & \\
Control & $3.06 \mathrm{a}^{\mathrm{z}}$ & $1.160 \mathrm{a}$ & $4.22 \mathrm{a}$ & $0.046 \mathrm{~b}$ \\
UV-A (314-400nm) & $3.25 \mathrm{a}$ & $1.213 \mathrm{a}$ & $4.46 \mathrm{a}$ & $0.048 \mathrm{~b}$ \\
FUV-B (290-400nm) & $3.26 \mathrm{a}$ & $1.293 \mathrm{a}$ & $4.55 \mathrm{a}$ & $0.058 \mathrm{ab}$ \\
UV-B (274-400nm) & $1.45 \mathrm{~b}$ & $0.772 \mathrm{~b}$ & $2.22 \mathrm{a}$ & $0.067 \mathrm{a}$ \\
& & Caesar red & \\
Control & $1.72 \mathrm{a}$ & $0.748 \mathrm{ab}$ & $2.47 \mathrm{a}$ & $0.364 \mathrm{~b}$ \\
UV-A (314-400nm) & $1.69 \mathrm{a}$ & $0.771 \mathrm{a}$ & $2.47 \mathrm{a}$ & $0.384 \mathrm{~b}$ \\
FUV-B (290-400nm) & $1.62 \mathrm{a}$ & $0.693 \mathrm{bc}$ & $2.32 \mathrm{a}$ & $0.662 \mathrm{a}$ \\
UV-B (274-400nm) & $1.26 \mathrm{~b}$ & $0.678 \mathrm{c}$ & $1.93 \mathrm{~b}$ & $0.625 \mathrm{a}$ \\
\hline
\end{tabular}

${ }^{\mathrm{z}}$ Values with the same letter within column are not significantly different at $p<.05$ according to Tukey's H.S.D. test.

Table 4. Responses of irradiations of different UV spectra on mineral contents in two romaine lettuce(Latuca sativa)

\begin{tabular}{lccccc}
\hline UV treatments & $\mathrm{N}$ & $\mathrm{P}$ & $\begin{array}{c}\mathrm{K} \\
\left(\mathrm{mg} \cdot \mathrm{g}^{-1} \mathrm{DW}\right)\end{array}$ & $\mathrm{Ca}$ & $\mathrm{Mg}$ \\
\hline Control & $36.7 \mathrm{a}^{\mathrm{z}}$ & $8.54 \mathrm{a}$ & $40.70 \mathrm{a}$ & $11.18 \mathrm{a}$ & $1.93 \mathrm{ab}$ \\
UV-A (314-400nm) & $35.7 \mathrm{a}$ & $8.61 \mathrm{a}$ & $43.03 \mathrm{a}$ & $10.40 \mathrm{a}$ & $2.07 \mathrm{a}$ \\
FUV-B (290-400nm) & $34.6 \mathrm{a}$ & $8.73 \mathrm{a}$ & $39.63 \mathrm{a}$ & $12.23 \mathrm{a}$ & $1.83 \mathrm{ab}$ \\
UV-B (274-400nm) & $19.0 \mathrm{c}$ & $6.12 \mathrm{~b}$ & $27.73 \mathrm{~b}$ & $7.40 \mathrm{~b}$ & $1.49 \mathrm{~b}$ \\
& \multicolumn{7}{c}{ Caesar green } \\
Control & $27.0 \mathrm{a}$ & $7.13 \mathrm{a}$ & $31.07 \mathrm{a}$ & $5.91 \mathrm{a}$ & $1.71 \mathrm{a}$ \\
UV-A (314-400nm) & $29.8 \mathrm{a}$ & $7.01 \mathrm{a}$ & $29.20 \mathrm{a}$ & $5.62 \mathrm{a}$ & $1.76 \mathrm{a}$ \\
FUV-B (290-400nm) & $26.3 \mathrm{a}$ & $6.89 \mathrm{a}$ & $29.60 \mathrm{a}$ & $5.91 \mathrm{a}$ & $1.71 \mathrm{a}$ \\
UV-B (274-400nm) & $14.7 \mathrm{~b}$ & $4.52 \mathrm{~b}$ & $23.33 \mathrm{a}$ & $4.92 \mathrm{a}$ & $1.21 \mathrm{~b}$ \\
\hline
\end{tabular}

${ }^{\mathrm{z}}$ Values with the same letter within column are not significantly different at $p<.05$ according to Tukey's H.S.D. test.

genetic materials in red leaf lettuce are expressed by UV-B treatment, which is known to increase the content of flavonoid and anthocyanin (Park et al., 2007). Meanwhile, Joshi et al. (2007) suggested that damage symptoms caused by the wavelengths of UV-B are relieved by the wavelengths of UV-A. In the results of this study, there was no change in the content of anthocyanin caused by UV-A, and it will be necessary to further research changes in the chromatophore of crops depending on the method and time of UV-A treatment.

Table 4 shows the content of inorganic compounds in the two romaine lettuce cultivars in different UV treatment groups. Both the two cultivars did not show any difference in the content of N, P, K, Ca and Mg between the UV-A and FUV-B treatments. Meanwhile, the content of inorganic compounds in the UV-B treatment group was statistically significantly low. The total nitrogen content in Caesar green lettuce was $19.0 \mathrm{mg} \cdot \mathrm{g}^{-1}$, lower by $48 \%$ than that in non-treated Caesar green lettuce, and the content of phosphorus in Caesar green lettuce was $6.12 \mathrm{mg} \cdot \mathrm{g}^{-1}$, lower by $28 \%$ than that in non-treated Caesar green lettuce. The content of potassium, calcium and magnesium was also statistically significantly reduced. The total nitrogen content in Caesar red lettuce was $14.7 \mathrm{mg} \cdot \mathrm{g}^{-1}$, lower by $46 \%$ than non-treated Caesar red lettuce, and the content of phosphorus in Caesar red lettuce was $4.52 \mathrm{mg} \cdot \mathrm{g}^{-1}$, lower by $37 \%$ than non-treated Caesar red lettuce. The growth of leafy vegetables including lettuce grown in nutrient solution is known to be closely related to the 
accumulated content of inorganic compounds (Kim et al., 2001). Therefore, as the results of this study show, a decrease in the growth of lettuce leaves in the UV-B treatment group (Table 1) can be attributed to the suppressed growth of their subterranean part and the limited absorption of inorganic compounds.

\section{Conclusion}

The results of this study indicate that UV-A (314-400nm) treatment in cultivating two romaine lettuce cultivars (Caesar green and Caesar red) in a greenhouse does not affect changes in their growth and in the content of antioxidant compounds. FUV-B (290-400nm) treatment reduced the dry weight of the subterranean part of Caesar green lettuce but not the dry weight of the aerial part of Caesar green lettuce. FUV-B treatment was also found to statistically significantly increase the content of $\beta$-carotene, lutein and total phenolic compounds. Meanwhile, the growth of Caesar red lettuce in the FUV-B treatment group was found to increase the content of total phenolic compounds and anthocyanin both in the subterranean and aerial parts of lettuce. However, UV-B $(274-400 \mathrm{~nm})$ treatment significantly suppressed the growth of the two romaine lettuce cultivars, and also reduced the content of lutein and chlorophyll. When using UV treatment as a cultivation method to increase the functional compounds of romaine lettuce, the wavelengths of FUV-B are expected to increase the content of antioxdiant compounds and, thus, improve the quality of lettuce.

\section{References}

Barsig, M. and R. Malz. 2000. Fine structure, carbohydrates and photosynthetic pigments of sugar maize leaves under UV-B radiation. Environ. Exp. Bot. 43:121-130.

Behn, H., S. Tittmann, A. Walter, U. Schurr, G. Noga, and A. Ulbrich. 2010. UV-B transmittance of greenhouse covering materials affects growth and flavonoid content of lettuce seedlings. Eur. J. Hortic. Sci. 75(6):259-268.

Caldwell, C.R. and S.J. Britz. 2006. Effect of supplemental ultraviolet radiation on the carotenoid and chlorophyll composition of greenhouse-grown leaf lettuce (Lactuca sativa L.) cultivars. J. Food Compos. Anal. 19:637-644. DOI:10.1016/j.jfca.2005.12.016

Cen, Y.P. and J.F. Bornman. 1993. The effects of exposure to enhanced UV-B radiation on the penetration of monochromatic and polychromatic UV-B radiation in leaves of Brassica napus. Physiol. Plant. 87:249-255. DOI:10.1111/j.1399-3054.1993.tb01727.x

Ervin, E.H., X. Zhang, and J.H. Fike. 2004. Ultraviolet-B radiation damage on Kentucky bluegrass. III. cultivar effects. HortScience 39(6):1475-1477.

Green, A.E.S., T. Sawada, and E.P. Shettle. 1974. The middle ultraviolet reaching the ground. Photochem. Photobiol. 19(4):251-259. DOI:10.1111/j.1751-1097.1974.tb06508.x

Jain, K., S. Kataria, and K.N. Guruprasad. 2003. Changes in antioxidant defenses of cucumber cotyledons in response to UV-B and to the free radical generating compound AAPH. Plant Sci. 165(3):551-557. DOI:10.1016/S0168-9452(03)00214-0

Jeong, S.W., S.W. Hogewoning, and W. van Ieperen. 2014. Responses of supplemental blue light on flowering and stem extension growth of cut chrysanthemum. Sci. Hortic. 165:69-74. DOI:10.1016/j.scienta.2013.11.006

Jeong, S.W. and M.R. Huh. 2010. Growth inhibition and seedling injury in response to UV spectra and irradiation timing in plug-transplants of pepper (Capsicum annunm L.) and tomato (Solanum lycopersicum). J. Jpn. Soc. Hortic. Sci. 79(1):40-46. DOI:10.2503/jjshs1.79.40

Joshi, P.N., N.K. Ramaswamy, R.K. Iyer, J.S. Nair, M.K. Pradhan, S. Gartia, B. Biswal, and U.C. Biswal. 2007. Partial protection of photosynthetic apparatus from UV-B-induced damage by UV-A radiation. Environ. Exp. Bot. 59(2):166-172. DOI:10.1016/j.envexpbot.2005.11.005

Kakani, V.G., K.R. Reddy, D. Zhao, and K. Sailaja. 2003. Field crop responses to ultraviolet-B radiation: A review. Agric. 
For. Meteorol. 120(1):191-218. DOI:10.1016/j.agrformet.2003.08.015

Kim, H.Y. and M.S. Cho. 2001. Effects of enhanced ultraviolet-B radiation on plants. J. Bio-environ. Control 10(3):197-206.

Krizek, D.T., S.J. Britz, and R.M. Mirecki. 1998. Inhibitory effects of ambient levels of solar UV-A and UV-B radiation on growth of cv. New Red Fire lettuce. Physiol. Plant. 103(1):1-7. DOI:10.1034/j.1399-3054.1998.1030101.x

Krizek, D.T., R.M. Mirecki, and S.J. Britz. 1997. Inhibitory effects of ambient levels of solar UV-A and UV-B radiation on growth of cucumber. Physiol. Plant. 100(4):886-893. DOI:10.1111/j.1399-3054.1997.tb00014.x

Lee, S.Y., S.J. Lee, S.M. Seo, S.W. Lee, and S.W. Sim. 1999. Reusing techniques of nutrient solution for recycling hydroponic culture of lettuce. J. Bio-environ. Control 8(3):172-182.

Lichtenthaler, H.K. 1987. Chlorophyll and carotenoids: Pigments of photosynthetic biomembranes. Methods Enzymol. 148:350-382. DOI:10.1016/0076-6879(87)48036-1

Park, J.S., M.G. Choung, J.B. Kim, B.S. Hahn, J.B. Kim, S.C. Bae, K.H. Rho, Y.H. Kim, C.I. Cheon, M.K. Sung, and K.J. Cho. 2007. Genes up-regulated during red coloration in UV-B irradiated lettuce leaves. Plant Cell Rep. 26(4):507-516.

Rabino, I. and A.L. Mancinelli. 1986. Light, temperature, and anthocyanin production. Plant Physiol. 81(3):922-924.

Singh, A., M.T. Selvi, and R. Sharma. 1999. Sunlight-induced anthocyanin pigmentation in maize vegetative tissues. J. Exp. Bot. 50(339):1619-1625. DOI:10.1093/jxb/50.339.1619

Smith, J.L., D.J. Burritt, and P. Bannister. 2000. Shoot dry weight, chlorophyll and UV-B absorbing compounds as indicators of a plant's sensitivity to UV-B radiation. Ann. Bot. 86(6):1057-1063. DOI:10.1006/anbo.2000.1270

Stepleton, A.E. 1992. Ultraviolet radiation and plants: Burning questions. Plant Cell 4(11):1353-1358. DOI:10.1105/tpc.4.11.1353

Yao, Y., Y. Yang, J. Ren, and C. Li. 2006. UV-spectra dependence of seedling injury and photosynthetic pigment change in Cucumis sativus and Glycine max. Environ. Exp. Bot. 57(1-2):160-167. DOI;10.1016/j.envexpbot.2005.05.009

Yun, H.K., Y.C. Kim, T.C. Seo, S.G. Lee, K.Y. Kim, and J.G. Lee. 2003. Effects of various kinds of ultraviolet irradiation on growth and antioxidant contents of some leafy vegetables. Korean J. Hortic. Sci. Technol. 21(2):94-97.

Zhang, X., E.H. Ervin, and R.E. Schmidt. 2005. The role of leaf pigment and antioxidant levels in UV-B resistance of dark- and light-green Kentucky bluegrass cultivars. J. Am. Soc. Hortic. Sci. 130(6):836-841. 